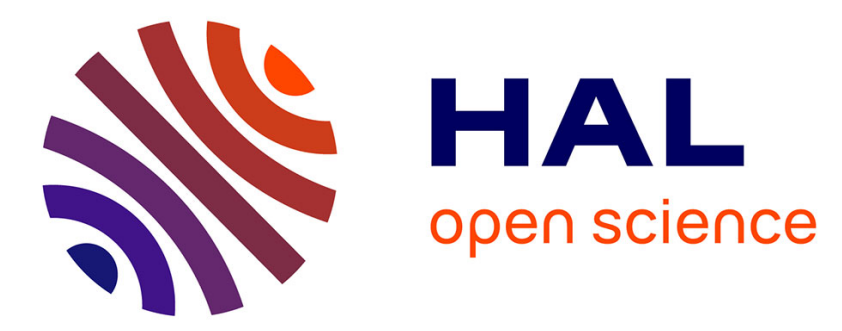

\title{
Population movements and the HIV cascade in recently diagnosed patients at the French Guiana -Suriname border
}

Raphaël Jaries, Vincent Vantilcke, Philippe Clevenbergh, Jocelyne Adoissi, Rachida Boukhari, Caroline Misslin, Mathieu Nacher, Stephen Vreden, Anne Jolivet

\section{To cite this version:}

Raphaël Jaries, Vincent Vantilcke, Philippe Clevenbergh, Jocelyne Adoissi, Rachida Boukhari, et al.. Population movements and the HIV cascade in recently diagnosed patients at the French Guiana -Suriname border . AIDS Care, 2017, [Epub ahead of print]. 10.1080/09540121.2017.1291899 . inserm-01476267

\section{HAL Id: inserm-01476267 https://www.hal.inserm.fr/inserm-01476267}

Submitted on 24 Feb 2017

HAL is a multi-disciplinary open access archive for the deposit and dissemination of scientific research documents, whether they are published or not. The documents may come from teaching and research institutions in France or abroad, or from public or private research centers.
L'archive ouverte pluridisciplinaire HAL, est destinée au dépôt et à la diffusion de documents scientifiques de niveau recherche, publiés ou non, émanant des établissements d'enseignement et de recherche français ou étrangers, des laboratoires publics ou privés. 
Population movements and the HIV cascade in recently diagnosed patients at the French Guiana Suriname border

Raphael Jaries ${ }^{a}$, Vincent Vantilcke $^{\mathrm{a}}$, Philippe Clevenbergh $^{\mathrm{c}}$, Jocelyne Adoissi ${ }^{\mathrm{a}}$, Rachida Boukhari $^{\mathrm{b}}$, Caroline Misslin $^{c}$, Mathieu Nacher ${ }^{\mathrm{d}}$, Stephen Vreden ${ }^{\mathrm{e}}$, Anne Jolivet $^{\mathrm{a}, \mathrm{f}}$

${ }^{a}$ Department of Public Health, Centre Hospitalier de I'Ouest Guyanais, Saint-Laurent du Maroni, French Guiana

${ }^{\mathrm{b}}$ Department of Clinical Biology, Centre Hospitalier de l'Ouest Guyanais, Saint-Laurent du Maroni, French Guiana

c Department of Medicine, Centre Hospitalier de I'Ouest Guyanais, Saint-Laurent du Maroni, French Guiana

d Centre d'Investigation Clinique Antilles-Guyane, INSERM 1424, Centre Hospitalier Andrée Rosemon, Av. des Flamboyants, 97306 Cayenne cedex, French Guiana

e Academic Hospital Paramaribo, Paramaribo, Surinam

f Sorbonne Universités, UPMC Univ Paris 06, INSERM, Institut Pierre Louis d'épidémiologie et de Santé Publique (IPLESP UMRS 1136), Department of social epidemiology, F75012, Paris, France 
ABSTRACT:

Border areas are particular "hot spots" generating high levels of HIV vulnerability and facing great challenges to control epidemics. The objective of this study is to describe the sociodemographic, clinical and biological profiles of newly HIV diagnosed people at the French Guiana-Suriname border, to construct an HIV care cascade and compare it with the Surinamese one. HIV-patients aged over 15 years newly diagnosed in western French Guiana in 2011 and 2012 were included in a retrospective cohort study. Patients were identified using different sources $(n=121)$. The male-tofemale ratio was $0.8,85 \%$ of the patients were of foreign origin, $72 \%$ were undocumented migrants, $21 \%$ were living in Suriname and $48 \%$ had baseline CD4 cell counts $<200$ cells $/ \mathrm{mm} 3$. After one year, $34 \%$ were lost to follow-up, $54 \%$ received treatment, $34 \%$ had controlled viremia and $6 \%$ died. We observed a disappointing HIV cascade, like that of Suriname, requiring to develop a coordinated healthcare offer on both sides of the border. Targeted efforts through a bi-national collaboration are needed to address the specific issues of cross-border patients to reach the 90*3 UNAIDS's diagnosis, link to care and treatment targets and better control the local epidemic.

KEY WORDS:

HIV, French Guiana, Suriname, Migrant, Health Policy 


\section{INTRODUCTION:}

There is growing evidence linking HIV prevalence and population mobility (International Organization for Migration [IOM], 2009). Mobile populations, and even more so undocumented migrants, constitute vulnerable populations at higher risk of HIV acquisition and lower access to care and support (Tanser, Bärnighausen, Vandormael, \& Dobra, 2015). In addition, some people living with HIV (PLHIV) may migrate to avoid stigmatization or to access comprehensive HIV care. Border areas are particular "hot spots" generating HIV vulnerability and facing great challenges to control epidemics (Espinoza, Hall, \& Hu, 2009; Hemhongsa et al., 2008; Lyttleton \& Amarapibal, 2002; Servin, Muñoz, \& Zúñiga, 2014). Transborder discrepancies in access to care and social services and lack of collaboration on health issues may further increase these challenges (Coker, Atun, \& McKee, 2004).

French Guiana (Guiana) is a French overseas territory. Saint Laurent du Maroni (SLM) lies along the Maroni River marking the French-Suriname border. There have been dramatic population changes since the early 90's, when civil war in Suriname forced a massive flux of refugees into western Guiana. In 2013 , the city counted 41,800 inhabitants, but its hospital serves an estimated 80,000 persons. It has a rapidly growing (+7\%/year), multicultural, multi-lingual, highly mobile population. Compared to the rest of the costal Guiana, the economy and the health care offer are less developed (Carde, 2009).

For 20 years, Guiana has had the highest HIV prevalence in France (Nacher et al., 2010). In 2014, 560 HIV patients were followed at SLM's hospital, representing $30 \%$ of all HIV patients followed in Guiana. The features of the HIV epidemic in western Guiana are unique. Concurrent partnerships may be one of the main drivers of the epidemic (Nacher et al., 2010), while stigma remains very high (van Melle et al., 2015). Mobile populations, notably boatmen (Gaubert-Marechal et al., 2012), had an important role in the rapid increase of HIV prevalence since the $90^{\prime}$ 's acting as a bridging 
group between vulnerable sex workers and the general population. However, mobility along and across the Maroni has many motives: economic (gold mining, and informal transborder's economy), farming and "family-related".

Guiana and Suriname are compared in Table 1. In eastern Suriname, clinics only provide primary care and only few HIV patients are followed (around 20 patients in 2014). Antiretroviral drugs (ARV) are available, but those requiring CD4-count, viral load, or radiology need to travel about $150 \mathrm{Km}$ to Paramaribo on their own expenses. There, public hospitals provide non-emergency care free of charge (FOC) for persons of Surinamese citizenship only.

The objective of the study was to describe the characteristics of newly diagnosed HIV-patients in western Guiana, to construct the HIV care cascade and compare it with the Surinamese one.

\section{METHODS:}

Between January $1^{\text {st }} 2011$ and December $31^{\text {st }} 2012$, all patients aged over 15 years, newly-diagnosed with HIV-infection in Western Guiana were included in a retrospective cohort analysis. Patients were identified from the French Hospital Database on HIV, from SLM's Hospital laboratory, or from other health providers involved in HIV-screening in western Guiana. Sociodemographic data (age, gender, country of birth, residency status, place of residence), characteristics of HIV screening (place and testing mode, baseline CD4 count), treatment outcome at one year were collected from medical records. Patients were considered "lost-to-follow up" if they had not consulted for $>6$ months.

The HIV-care cascade, was a denominator-denominator linked cascade which used the exact same group of individuals for all stages of the cascade (Haber, Pillay, Porter, \& Bärnighausen, 2016). We constructed 4 stages, using the same definitions as the Surinamese cascade (MoH Suriname, 2015) : "HIV diagnosed", "Linked to HIV-Care" (at least one CD4 count), "on ART" (initiation of ART) and 
"suppressed viral load" (at least one estimation of viral load $\leq 1000$ copies/ml after 6 to 12 months of treatment).

This protocol was approved by the institutional review board of the SLM Hospital.

Statistical analysis was carried out with Epi Info 7 software.

RESULTS:

The study included 121 patients. Sociodemographic, screening and baseline data are described in table 1. Most new HIV patients were females (56\%), born in Suriname (60\%) and undocumented (72\%). Most patients (56\%) lived in SLM and 21\% in Suriname (Paramaribo 12\%, Albina: 5\%, other: $4 \%) .48 \%$ had baseline CD4 cell counts $<200 / \mathrm{mm}^{3}$. A small proportion of cases (9\%) had previously been diagnosed; mostly (9/11) in Suriname. At one year, $34 \%$ were lost to follow-up, $6 \%$ were referred to another clinic and $6 \%$ had died.

Figure 1 represents the HIV care cascades in western Guiana and Suriname between 2007 and 2012. Among the 121 HIV-diagnosed patients, 89\% were linked to HIV care. Treatment was indicated for $74 \%$ of the patients and initiated in $73 \%$ of them. Forty-one patients (34\%) had viral load $<1000$ copies/ml after 6 months. Other patients were either non-adherent to therapy (21\%) or were not tested for viral load (79\%). Using a threshold at 50 copies/ml, we found a $29 \%$ suppression rate. The migratory status did not influence the cascade. Forty-seven treated patients were tested for HIV drug-resistance and 9 (19\%) presented resistances to ARVs: $6(12.8 \%)$ to at least one NNRTI, 4 (8.5\%) to NRTI, $1(2.1 \%)$ to PI and $2(4.2 \%)$ to NtRTI. Three out of eight (38\%) known HIV-infected patients showed HIV drug-resistance.

DISCUSSION:

Most of newly diagnosed HIV-infected patients were women, contrarily to mainland France (2.1) (Morlat, 2013) and to other parts of Guiana (1) (Melin, 2014). However, this is similar to the 
Caribbean Region (UNAIDS, 2012), where HIV/AIDS disproportionately affects women and adolescent girls.

Most of patients were of foreign origin (85\%) with a precarious legal status (72\% were undocumented migrants), whereas among the general adult population living in SLM these proportions are estimated at 58\% and 26\%, respectively (Jolivet et al., 2012). Migrants and undocumented migrants are therefore overrepresented among PLHIV.

Almost half (48\%) of patients had low baseline CD4 cell counts, whereas this proportion was $29 \%$ for patients followed in Cayenne Hospital (Regional Coordination Center for the Fight against HIV [COREVIH - French Guiana], 2015). The death rate at one year (6\%) was much higher compared to the whole Guiana HIV cohort where it dropped below 1\% per year since 2005 (COREVIH, 2015).

Twenty-one per cent of the patients in care at SLM were currently living in Suriname. HIV-infection was already diagnosed in Suriname for $7 \%$ of the cohort. Some of them may have received treatment in Suriname. The proximity and the perception of having better healthcare facilities in SLM was one of the main reasons for patients living in Suriname to seek pregnancy and emergency care in SLM's hospital (Jolivet, Florence, Lebas, \& Chauvin, 2010). The high level of stigmatisation in that area (van Melle et al., 2015) is probably an additional factor to seek HIV care elsewhere. Unfortunately, we did not have information on patient itineraries. Further research should aim to better understand Surinamese patients' health seeking itineraries. Migration of PLHIV across the border has considerable implications in relation to health service provision and public health surveillance systems. Therefore, in Suriname as well as in Western Guiana, the estimation of HIVprevalence as well as the whole HIV care cascade may be affected.

We observed a disappointing HIV care cascade where only $34 \%$ of the cohort had controlled viremia mainly due to the high rate of lost to follow-up. In comparison with the Surinamese HIV cascade (MoH Suriname, 2015), more patients were linked to care and on ART in Guiana (where treatment initiation threshold is higher), but we found a similar rate of patients lost to follow-up after treatment initiation. Some patients lost to follow-up in Suriname could presumably be found in 
SLM and vice-versa. Factors associated with follow-up interruption could not be identified in this small study. Other local studies (Nacher et al., 2006) showed that younger patients, foreigners and undocumented patients were more likely to be lost to follow-up, as well as those not receiving any treatment or with $\mathrm{CD} 4<500 \mathrm{~mm} / 3$ when diagnosed. Precarious living conditions of migrants, presumably explain adherence difficulties. In Guiana, the full healthcare package including ARV according to French national guidelines is accessible FOC to all patients, including undocumented migrants, under the precept of emergency care. However, provision of chronic care is hampered by administrative hurdles and discriminations in accessing health services (Carde, 2007) leading to frequent disruptions in health insurance and follow-up. Linguistic barriers, illiteracy, lack of information and support in mother tongue may also explain these results.

Finally, as a probable consequence of cross-border patient mobility and low adherence, we observed a high prevalence of drug resistance among our cohort: $19 \%$ compared to $12.2 \%$ in France among newly diagnosed HIV patients (Morlat, 2013), 6.3\% in Latin America and the Caribbean Region (Frentz, Boucher, \& Van De Vijver, 2012), and 4.6\% in the whole Guiana (among treatment-naive patients with a CD4 cell count above 350/mm3) (Darcissac et al., 2016). This makes research and coordinated strategies urgent in this area.

The main limitations of the study were the small study population, the retrospective design and the frequent missing data. Moreover, our cascade, was based on a limited number of patients during a limited period and did not include undiagnosed HIV. With an estimation of $40 \%$ of undiagnosed HIV (MoH Suriname, 2015), our rate of suppressed viral load would drop to $20 \%$. Finally, the comparison with Surinamese's cascade is also limited because of different time-frames and different methods in data surveillance and data analysis.

CONCLUSION: 
Our study shows that PLHIV living on the French-Suriname border are vulnerable and deserve specific attention. This requires bi-national collaboration to address the specific issues of crossborder patients. Both countries should first reinforce the care offer and facilitate its access. Both systems must work together to systematize exchanges of medical information to support continuity of care for mobile patients. Joint research efforts should aim to better estimate and understand the high level of follow-up interruption in both countries. Much remains to be done in the general population, to provide information on HIV transmission, improve testing and reduce stigma and discrimination. A strong support from national and regional health authorities is essential in both countries to reach these goals. 


\section{REFERENCES:}

Carde, E. (2007). Les discriminations selon l'origine dans l'accès aux soins. Santé Publique, 19(2), 99. http://doi.org/10.3917/spub.072.0099

Carde, E. (2009). The French Health Care System Challenged by the Over-Sea : Some Inequalities in French Guyana. Espace Populations Sociétés, 1, 175-189.

Coker, R. J., Atun, R. A., \& McKee, M. (2004). Health-care system frailties and public health control of communicable disease on the European Union's new eastern border. Lancet (London, England), 363(9418), 1389-92. http://doi.org/10.1016/S0140-6736(04)16053-4

Darcissac, E., Nacher, M., Adriouch, L., Berlioz-Arthaud, A., Boukhari, R., Couppié, P., ... Lacoste, V. (2016). HIV-1 Pol Gene Polymorphism and Antiretroviral Resistance Mutations in TreatmentNaive Adult Patients in French Guiana Between 2006 and 2012. AIDS Research and Human Retroviruses. http://doi.org/10.1089/AID.2016.0048

Espinoza, L., Hall, H. I., \& Hu, X. (2009). Increases in HIV diagnoses at the U.S.-Mexico border, 20032006. AIDS Education and Prevention : Official Publication of the International Society for AIDS Education,21(5Suppl), 19-33.http://doi.org/10.1521/aeap.2009.21.5_supp.19

Frentz, D., Boucher, C. A. B., \& Van De Vijver, D. A. M. C. (2012). Temporal changes in the epidemiology of transmission of drug-resistant HIV-1 across the world. AIDS Reviews. Retrieved from http://www.ncbi.nlm.nih.gov/pubmed/22297501

Gaubert-Marechal, E., Jolivet, A., Van Melle, A., Parriault, M.-C., Basurko, C., Adenis, A., ... Nacher, M. (2012). Knowledge, Attitudes, Beliefs and Practices on HIV/AIDS among Boatmen on the Maroni River: A Neglected Bridging Group? Journal of AIDS \& Clinical Research, 03(09). http://doi.org/10.4172/2155-6113.1000181

Haber, N., Pillay, D., Porter, K., \& Bärnighausen, T. (2016). Constructing the cascade of HIV care: methods for measurement. Current Opinion in HIV and AIDS, 11(1), 102-8. http://doi.org/10.1097/COH.0000000000000212 
Hemhongsa, P., Tasaneeyapan, T., Swaddiwudhipong, W., Danyuttapolchai, J., Pisuttakoon, K., Rienthong, S., ... Varma, J. K. (2008). TB, HIV-associated TB and multidrug-resistant TB on Thailand's border with Myanmar, 2006-2007. Tropical Medicine \& International Health : TM \& IH, 13(10), 1288-96. http://doi.org/10.1111/j.1365-3156.2008.02139.x

International Organization for Migration (IOM). (2009). HIV and Mobility: Compendium of Migration and HIV and Aids Interventions. Geneva: IOM.

Jolivet, A., Cadot, E., Florence, S., Lesieur, S., Lebas, J., \& Chauvin, P. (2012). Migrant health in French Guiana: Are undocumented immigrants more vulnerable? BMC Public Health.

Jolivet, A., Florence, S., Lebas, J., \& Chauvin, P. (2010). Migration, health, and care in French overseas territories. Lancet (London, England), 376(9755), 1827-8. http://doi.org/10.1016/S0140$6736(10) 62169-1$

Lyttleton, C., \& Amarapibal, A. (2002). Sister cities and easy passage: HIV, mobility and economies of desire in a Thai/Lao border zone. Social Science \& Medicine (1982), 54(4), 505-18. Retrieved from http://www.ncbi.nlm.nih.gov/pubmed/11848271

Melin, M. (2014). Surveillance des infections à VIH et du SIDA dans les départements français d’Amérique: données 2013 et évolutions depuis 2003. Bulletin de Veille Sanitaire, 6, 2-9.

Morlat, P. (2013). Prise en charge médicale des personnes vivant avec le VIH. Recommandations du groupe d'experts. Rapport 2013. [French 2013 Experts' recommendations for the management of people living with HIV/AIDS]. Paris : La documentation française.

Nacher, M., El Guedj, M., Vaz, T., Nasser, V., Randrianjohany, A., Alvarez, F., ... Couppié, P. (2006). Risk factors for follow-up interruption of HIV patients in French Guiana. The American Journal of Tropical Medicine and Hygiene, 74(5), 915-7. Retrieved from http://www.ncbi.nlm.nih.gov/pubmed/16687702

Nacher, M., Vantilcke, V., Parriault, M. C., Van Melle, A., Hanf, M., Labadie, G., ... Couppié, P. (2010). What is driving the HIV epidemic in French Guiana? International Journal of STD \& AIDS, 21(5), 359-61. http://doi.org/10.1258/ijsa.2010.009570 
Servin, A. E., Muñoz, F. A., \& Zúñiga, M. L. (2014). Healthcare provider perspectives on barriers to HIV-care access and utilisation among Latinos living with HIV in the US-Mexico border. Culture, Health \& Sexuality, 16(5), 587-99. http://doi.org/10.1080/13691058.2014.886131

Sudrie, O. (2013). Quel niveau de développement des départements et collectivités d'outre-mer? Une approche par l'indice de développement humain. Paris: Agence Française du Développement. Retrieved from http://www.afd.fr/jahia/webdav/site/afd/shared/PUBLICATIONS/RECHERCHE/Scientifiques/Do cuments-de-travail/129-document-travail.pdf

Mnistery of Health (MoH) Suriname (2015). Suriname AIDS Response Progress Report 2015. Retrieved from http://www.unaids.org/sites/default/files/country/documents/SUR_narrative_report_2015.pdf Regional Coordination Center for the Fight against HIV (COREVIH - French Guiana). (2015). COREVIH French Guiana 2015 activity report. Centre Hospitalier Andrée Rosemon, Cayenne. Retrieved from : http://www.chcayenne.net/IMG/pdf/ultime_version_du_ra_2015_corevih_03.02.2016.pdf

Tanser, F., Bärnighausen, T., Vandormael, A., \& Dobra, A. (2015). HIV treatment cascade in migrants and mobile populations. Current Opinion in HIV and AIDS, 10(6), 430-438. http://doi.org/10.1097/COH.0000000000000192

UNAIDS. (2012). Regional Fact Sheet 2012: Latin America and the Caribbean'.

van Melle, A., Parriault, M.-C., Basurko, C., Jolivet, A., Flamand, C., Pigeon, P., ... Nacher, M. (2015). Prevalence and predictive factors of stigmatizing attitudes towards people living with HIV in the remote villages on the Maroni River in French Guiana. AIDS Care, 27(2), 160-7. http://doi.org/10.1080/09540121.2014.939607 
Figure 1: The HIV care cascade in Western French Guiana (2011-2012) and Suriname (2007-2012)

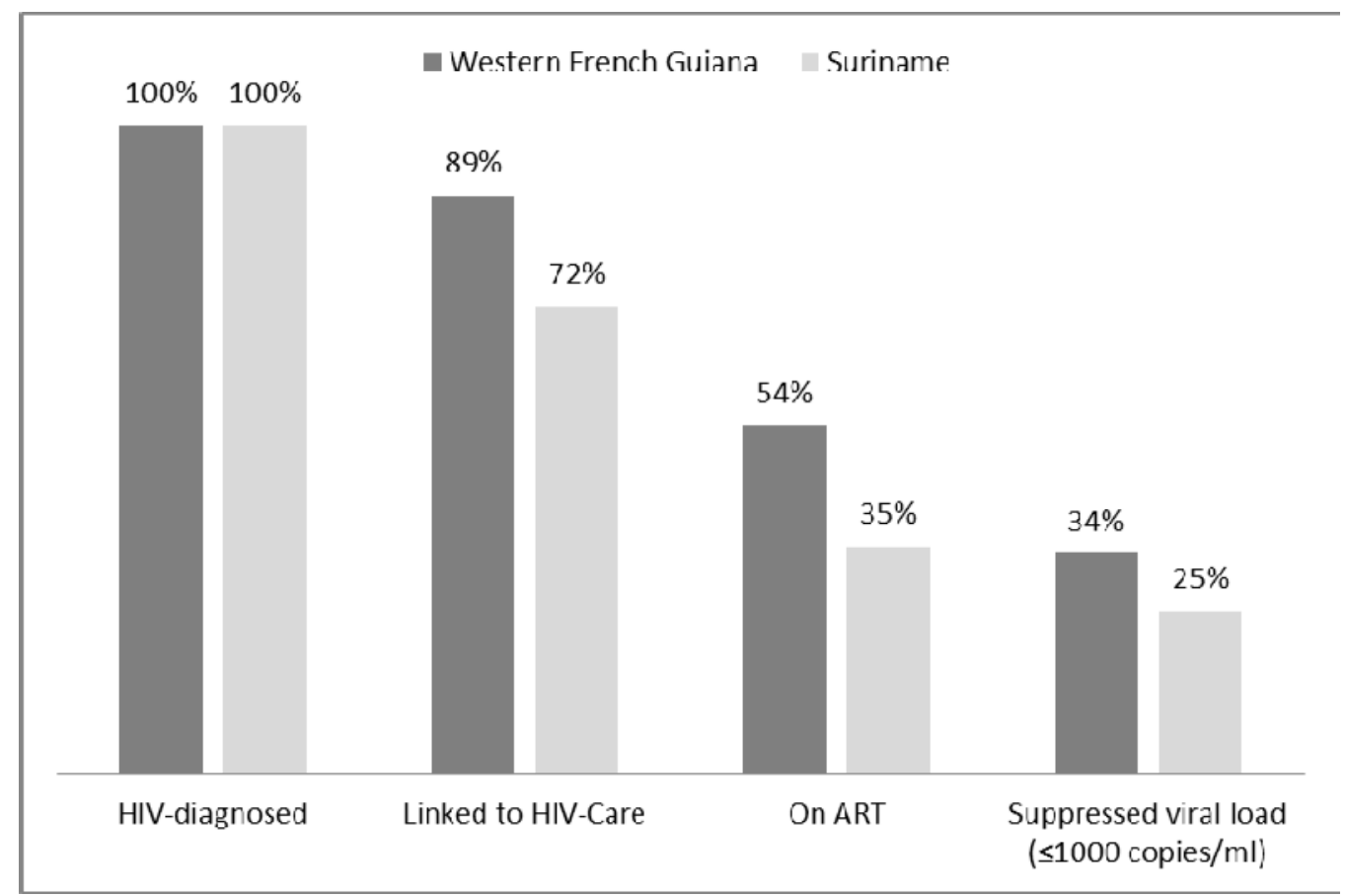


Table 1 : General and HIV data in French Guiana and Suriname

\begin{tabular}{|c|c|c|}
\hline & French Guiana & Suriname \\
\hline Density $\left(\mathrm{km}^{2}\right)$ & 83530 & 163820 \\
\hline Population (2014) & 250380 & 568000 \\
\hline Human Development Index (2010) & $0,739 *$ & $0,707 * *$ \\
\hline HIV prevalence among pregnant women & $1.14 \%(2014)^{* * *}$ & $0.9 \%(2010)^{\ddagger}$ \\
\hline Number of new HIV diagnoses (up to 2013) & $2549^{\neq \neq}$ & $7090^{\ddagger}$ \\
\hline Number of new HIV diagnosesin 2013 & $148^{f \neq}$ & $473^{\ddagger}$ \\
\hline Number of HIV patients on ART (2013) & $1461^{\neq \neq}$ & $1343^{\ddagger}$ \\
\hline \multicolumn{3}{|l|}{ * (Sudrie, 2013) } \\
\hline \multicolumn{3}{|l|}{ ** UNDP (Suriname) } \\
\hline \multicolumn{3}{|c|}{ *** French Guiana regional register of births (2014) } \\
\hline ‡ (MoH Suriname, 2015) & & \\
\hline
\end{tabular}


Table 2: Patients characteristics

\begin{tabular}{|c|c|c|c|}
\hline & & $\mathrm{N}$ & $\%$ \\
\hline \multirow[t]{2}{*}{ Gender } & Male & 53 & 43.8 \\
\hline & Female & 68 & 56.2 \\
\hline Age (at diagnosis) & Among male & \multicolumn{2}{|c|}{$39.9 \pm 10.4$} \\
\hline (Mean \pm SD) & Among female & \multicolumn{2}{|c|}{$34.8 \pm 12.1$} \\
\hline \multirow[t]{6}{*}{ Country of birth } & French Guiana & 18 & 14.9 \\
\hline & Suriname & 73 & 60.3 \\
\hline & Brazil & 11 & 9.1 \\
\hline & Guyana & 10 & 8.3 \\
\hline & Haiti & 8 & 6.6 \\
\hline & Dominican Republic & 1 & 0.8 \\
\hline \multirow[t]{4}{*}{ Residency status } & French citizens & 18 & 17.8 \\
\hline & Regular migrant & 10 & 9.9 \\
\hline & Irregular migrant & 73 & 72.3 \\
\hline & Missing data & 20 & - \\
\hline \multirow[t]{4}{*}{ Place of residence } & St-Laurent du Maroni & 66 & 55.5 \\
\hline & Other city/village in French Guiana & 29 & 24.2 \\
\hline & City/village in Suriname & 25 & 20.8 \\
\hline & Missing data & 1 & - \\
\hline \multirow[t]{6}{*}{ Place of screening } & St-Laurent Hospital & 68 & 56.1 \\
\hline & Family doctors & 21 & 17.4 \\
\hline & Red-Cross & 14 & 11.6 \\
\hline & AIDES & 9 & 7.4 \\
\hline & Clinics & 6 & 5.0 \\
\hline & Other & 3 & 2.5 \\
\hline \multirow[t]{2}{*}{ Mode of screening } & Blood test & 105 & 86.8 \\
\hline & Rapid HIV Test & 16 & 13.2 \\
\hline \multirow[t]{6}{*}{ Motives for screening } & Opportunistic testing & 33 & 32.0 \\
\hline & Clinical symptom* & 48 & 46.6 \\
\hline & Pregnancy & 11 & 10.7 \\
\hline & Partner HIV+ & 7 & 6.8 \\
\hline & HIV already known & 4 & 3.9 \\
\hline & Missing data & 18 & - \\
\hline \multirow[t]{2}{*}{ Previous diagnosis } & Yes & 11 & 9.1 \\
\hline & No & 110 & 90.9 \\
\hline \multirow[t]{4}{*}{ CD4 count at screening } & $C D 4<200$ & 47 & 47.5 \\
\hline & $200 \leq C D 4<500$ & 29 & 29.3 \\
\hline & $500 \leq \mathrm{CD} 4$ & 23 & 23.2 \\
\hline & Missing data & 22 & - \\
\hline \multirow[t]{3}{*}{ Co-infection Rates } & $\mathrm{HIV} / \mathrm{HBV}$ & 6 & 5.0 \\
\hline & $\mathrm{HIV} / \mathrm{HCV}$ & 0 & 0 \\
\hline & $\mathrm{HIV} / \mathrm{HTLV}$ & 7 & 5.8 \\
\hline \multirow[t]{5}{*}{ Outcome at one year } & Follow-up & 65 & 53.7 \\
\hline & Lost to follow-up & 41 & 33.9 \\
\hline & Addressed to other specialized care & 8 & 6.6 \\
\hline & Died & 7 & 5.8 \\
\hline & Total & 121 & 100.0 \\
\hline
\end{tabular}

* including : Deterioration of general status (weight loss, asthenia, anorexia) (24), isolated fever (4) , diarrhea (4), primoinfection (2), Opportunistic infection (zona (3), histoplasmosis (2), TB (2), candidosis (1)), neurologic symptom (2), dermatosis (1), other STD (2), other (1). 